\title{
Simple anonychia congenita
}

\section{Mrinal Gupta}

Department of Dermatology, Treatwell Skin Centre, Jammu and Kashmir, India

Corresponding author: Dr. Mrinal Gupta, E-mail: drmrinalgupta@yahoo.com

A 10-year-old male presented with absence of all nails since birth (Fig. la and lb). On examination, there was absence of all finger nails and toenails. No abnormality of the bone and teeth was present. Radiography of both hands and feet showed no abnormality. The patient had normal intelligence. There was no family history. Based on the clinical features and history, a diagnosis of congenital nonsyndromic simple partial anonychia was made.

Anonychia (absence of nails) is a very rare congenital or acquired anomaly. It may occur as a single feature or as part of a syndrome. Nonsyndromic anonychia has been reported in either partial or total forms. Simple anonychia means congenital absence of the nails without any other coexisting major congenital anomaly, and is extremely rare [1]. It is caused due to frameshift and nonconservative missense mutation in the exon 2 of R-spondin 4 gene present on chromosome $20 \mathrm{pl3}$, which affects the highly conserved first furinlike cysteine-rich domain that plays a crucial role in nail morphogenesis, resulting in absence of nails [2].

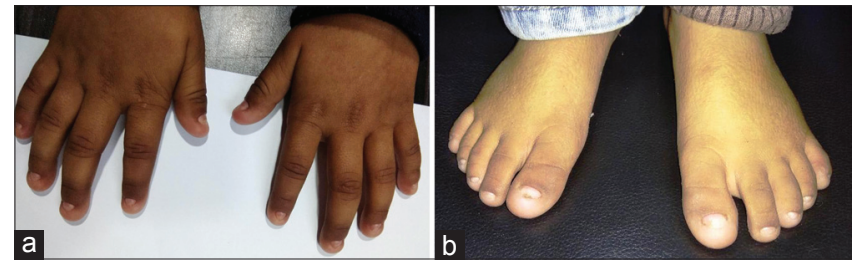

Figure 1: $(a$ and $b)$ Complete absence of all fingernails and toenails.

Treatment remains masterly inactivity or artificial nails.

\section{REFERENCES}

1. Yadalla HK, Nitya R, Sujatha C. A rare case of isolated congenital complete simple anonychia. Int J Health Allied Sci. 2012;1:32-3.

2. Blaydon DC, Ishii Y, O’Toole EA, Unsworth HC, Teh MT, Rüschendorf F, et al. The gene encoding r-spondin 4 (RSPO4), a secreted protein implicated in wnt signaling, is mutated in inherited anonychia. Nat Genet. 2006;38:1245-7.

Copyright by Mrinal Gupta. This is an open-access article distributed under the terms of the Creative Commons Attribution License, which permits unrestricted use, distribution, and reproduction in any medium, provided the original author and source are credited.

Source of Support: Nil, Conflict of Interest: None declared. 